\title{
Pedicled Anterolateral Thigh Flap as a Workhourse Flap for Reconstruction of Inguino-Scrotal Defects
}

Mukesh Sharma ${ }^{1}$, Naveen Kumar ${ }^{2 *}$, V Suman Babu ${ }^{3}$

${ }^{1}$ Assosiate Professor, Department of Burns, Plastic and Reconstructive Surgery Pgimer and Dr. RML Hospital, New Delhi, India ${ }^{2}$ Assistant Professor, Department of Plastic Surgery Lady Hardinge Medical College and Associated Hospital, New Delhi, India ${ }^{3}$ Assistant Professor, Department of Burns, Plastic and Reconstructive Surgery Pgimer and Dr. RML Hospital, New Delhi, India

Correspondence to: Naveen Kumar, Assistant Professor, Department of Plastic Surgery Lady Hardinge Medical College and Associated Hospital, New Delhi, India. Received date: October 2, 2021; Accepted date: October 14, 2021; Published date: October 21, 2021

Citation: Sharma M, Kumar N, Babu VS (2021) Pedicled Anterolateral Thigh Flap As A Workhourse Flap for Reconstruction of Inguino-Scrotal Defects. J Med Res Surg 2(S3): pp. 1-5. doi: 10.52916/jmrs21S103

Copyright: (C2021 Sharma M, et al. This is an open-access article distributed under the terms of the Creative Commons Attribution License, which permits unrestricted use, distribution and reproduction in any medium, provided the original author and source are credited.

\section{ABSTRACT}

Background: Reconstructions around inguinoscrotal region has been a challenging task owing to complex anatomy. There are variety of flap options available for reconstruction of Inguinoscrotal region. Our study was done to evaluate the use of pedicled anterolateral thigh flap for reconstruction of defects around inguinoscrotal regions.

Methodology: In this study a total of 18 patients with various types of defects around inguinoscrotal region were evaluated. The etiology of defects included trauma $(n=6)$, infection $(n=8)$, malignancy $(n=2)$ and burn $(n=2)$. Patients were evaluated in terms of viability of the flap, number of perforators included, pedicled length and flap dimensions and donor site morbidity.

Results: All flaps were survived well except 1 flap develop venous congestion in immediate post operative period due to tension over vascular pedicle which was managed by increasing pedicle length. 2 patients had developed partial loss of the skin graft at the donor site which got healed secondarily in due course. All patients were followed up for an average period of 6 months, ranging from 1 to 12 months. Donor site morbidity was minimal.

Conclusion: Pedicled ALT flap is a versatile, reliable flap, with wide arc of rotation which makes it as an ideal flap for the coverage of defects around inguinoscrotal region.

\section{Keywords:}

Flap, Defect, Cover, Groin, Scrotum.

\section{Abbreviations:}

ALT: Anterolateral Thigh; ALTP: Anterolateral Thigh Perforator; LCFA: Lateral Circumflex Femoral Artery; TFL: Tensor Fascia Lata; VRAM: Vertical Rectus Abdominis Muscle.

\section{Introduction}

Reconstructions around inguino-scrotal region has been a challenging task owing to complex anatomy related to genitals, urethra, perineum and possible femoral vessels exposure, maceration in the folds, and contamination with urinary and fecal pathogens. There are variety of flap options available for reconstruction of inguinoscrotal region. An ideal flap should be versatile to be tailored to different types of defects, should have low donor site morbidity, have a long pedicle, be capable of carrying huge amounts of different tissues (skin, fat, fascia or muscle) according to reconstructive needs, and have a strong vascularization to allow fast healing and low rate of complications.) Since its introduction by Song et al., [1]. Anterolateral Thigh Perforator (ALT) flap has been extensively used both as pedicled and free flap. A number of investigators have used the flap for breast, head, forelimb, vulvovaginal, perineal, and inguinal reconstruction with considerable results [2]. ALTP gained popularity after initial reports of anatomic description and clinical applications from Asian countries showed favorable outcomes.

\section{Methodology}

The study was conducted where a total of 18 patients with various types of defects around Inguinoscrotal region had undergone reconstruction with pedicled ALT flap at our institute. The duration of the study was from August 2018 to January 2020. A total of 19 ALT flaps were used (bilateral in one case) for the coverage of the defects. Age group ranged from 15-68 years (Mean $44 \mathrm{yr}$ ) 17 male and 1 female patient. Out of the 18 patients, 06 patients had defects secondary to groin node dissection tailor it to different geometries of defects, in reconstructing complex defects, defined as the association of more than one anatomical subunit resection.

A retrospective review of the medical records of 18 patients who underwent 19 pedicled Anterolateral thigh flaps for complex Inguinoscrotal reconstruction was evaluated (Table 1).

Out of total 18 patients 1 for carcinoma penis, (bilaterally). 4 patient underwent for fournier's gangrene (Figure 1), 2 for burns and 6 for trauma (Figure 2-3) and 1 female patient underwent reconstruction for SCC excision, 4 for post Inguinoscrotal dissection wound dehiscence (Figure 4). The size of the defect ranged from $7 \times 4 \mathrm{~cm}$ to $26 \times 13 \mathrm{~cm}$. 19 defects in 18 patients were covered with fasciocutaneous flaps and in one case perforator based myo fasciocutaneous anterolateral thigh flap was used. In 13 cases, the donor site was closed primarily and in 6 cases of large defects, split thickness skin graft was required 
Table 1: Anterolateral thigh flap for inguinoscrotal defect reconstruction.

\begin{tabular}{|c|c|c|c|c|c|c|c|c|c|c|c|c|}
\hline No & $\begin{array}{l}\text { Age / } \\
\text { Sex }\end{array}$ & Diagnosis & $\begin{array}{l}\text { Co- } \\
\text { morbidity }\end{array}$ & Flap & $\begin{array}{l}\text { Type } \\
\text { of } \\
\text { Flap }\end{array}$ & Coverage & $\begin{array}{l}\text { No of } \\
\text { Perforators }\end{array}$ & $\begin{array}{l}\text { Branching } \\
\text { pattern }\end{array}$ & $\begin{array}{l}\text { Flap } \\
\text { Size }\end{array}$ & $\begin{array}{l}\text { Perf } \\
\text { type }\end{array}$ & $\begin{array}{l}\text { Donor } \\
\text { site }\end{array}$ & $\begin{array}{l}\text { Follow } \\
\text { Up }\end{array}$ \\
\hline 1. & $68 \mathrm{M}$ & $\begin{array}{l}\text { PostFoumier } \\
\text { Soft tissue defect } \\
\text { Scrotum }\end{array}$ & Old age & $\begin{array}{l}\text { Lt } \\
\text { ALT }\end{array}$ & $\overline{F C}$ & Scrotum & 01 & $\begin{array}{l}\text { Transverse } \\
\text { Branch } \\
\text { Poor perforators } \\
\text { from Descending } \\
\text { Branch }\end{array}$ & $16 \times 8$ & $\mathrm{MC}$ & SSG & $\mathrm{Nil}$ \\
\hline 2. & $45 \mathrm{M}$ & $\begin{array}{l}\text { Trauma Scrotum } \\
\text { plus left groin }\end{array}$ & $\mathrm{N} 1$ & $\begin{array}{l}\text { Rt } \\
\text { ALT }\end{array}$ & $\mathrm{FC}$ & $\begin{array}{l}\text { Scrotum \& Left } \\
\text { Groin }\end{array}$ & 03 & $\begin{array}{l}\text { Descending } \\
\text { Branch }\end{array}$ & $\begin{array}{l}20 \times 10 \\
\mathrm{~cm}\end{array}$ & MC & SSG & $\mathrm{NI}$ \\
\hline 3. & $51 / \mathrm{M}$ & $\begin{array}{l}\text { PostFoumier } \\
\text { Soft tissue defect } \\
\text { Scrotum }\end{array}$ & $\begin{array}{l}\text { Diabetic \& } \\
\text { Smoker }\end{array}$ & $\begin{array}{l}\text { Lt } \\
\text { ALT }\end{array}$ & $\mathrm{MC}$ & $\begin{array}{l}\text { Scrotum \& } \\
\text { perineum }\end{array}$ & 01 & $\begin{array}{l}\text { Descending } \\
\text { Branch }\end{array}$ & $\begin{array}{l}12 \times 8 c \\
m\end{array}$ & $\mathrm{MC}$ & $\begin{array}{l}\text { Primary } \\
\text { dosure }\end{array}$ & $\begin{array}{l}\text { Partial } \\
\text { necrosis \& } \\
\text { Wound } \\
\text { Dehiscence }\end{array}$ \\
\hline 4. & $45 / M$ & $\begin{array}{l}\text { Post Foumier } \\
\text { Soft tissue defect } \\
\text { Inguinoscrotal }\end{array}$ & $\mathrm{Na}$ & $\begin{array}{l}\text { Lt } \\
\text { ALT }\end{array}$ & $\mathrm{FC}$ & Ingumoscrotum & 01 & $\begin{array}{l}\text { Descending } \\
\text { Branch }\end{array}$ & $12 \times 7$ & $\mathrm{MC}$ & $\begin{array}{l}\text { Primary } \\
\text { Closure }\end{array}$ & $\mathrm{NI}$ \\
\hline 5. & $68 / F$ & $\begin{array}{l}\text { SCC Ingumal } \\
\text { region }\end{array}$ & Diabetic & $\begin{array}{l}\text { Lt } \\
\text { ALT }\end{array}$ & $F C$ & Grom & 01 & $\begin{array}{l}\text { Descending } \\
\text { Branch }\end{array}$ & $9 \times 8$ & $\mathrm{SC}$ & $\begin{array}{l}\text { Primary } \\
\text { Closure }\end{array}$ & $\begin{array}{l}\text { Venous } \\
\text { Congestion }\end{array}$ \\
\hline 6. & $63 / \mathrm{M}$ & $\begin{array}{l}\text { Post lliomgumal } \\
\text { block dissection } \\
\text { soft tissue defect } \\
\text { groin }\end{array}$ & $\mathrm{N}$ 1 & $\begin{array}{l}\mathrm{Rt} \\
\mathrm{ALT}\end{array}$ & $\mathrm{FC}$ & Grom & 02 & $\begin{array}{l}\text { Descending } \\
\text { branch }\end{array}$ & $9 \times 6$ & $\mathrm{MC}$ & $\begin{array}{l}\text { Primary } \\
\text { closure }\end{array}$ & NI \\
\hline 7. & $17 / \mathrm{M}$ & $\begin{array}{l}\text { Post electrical } \\
\text { Bum Groin soft } \\
\text { tissue defect }\end{array}$ & $\begin{array}{l}\text { Electrical } \\
\text { Burn } \\
\text { gangrenou } \\
\text { s Rt upper } \\
\text { limb } \\
\end{array}$ & $\begin{array}{l}\mathrm{Rt} \\
\mathrm{ALT}\end{array}$ & FC & Groin & 01 & $\begin{array}{l}\text { Descending } \\
\text { branch }\end{array}$ & $10 \times 6$ & MC & $\begin{array}{l}\text { Primary } \\
\text { closure }\end{array}$ & Nil \\
\hline
\end{tabular}

\begin{tabular}{|c|c|c|c|c|c|c|c|c|c|c|c|c|}
\hline 8. & $60 \mathrm{M}$ & $\begin{array}{l}\text { Post llioinguinal } \\
\text { block dissection } \\
\text { soft tissue defect } \\
\text { groin }\end{array}$ & Diabetic & $\begin{array}{l}\text { Lt } \\
\text { ALT }\end{array}$ & $\mathrm{FC}$ & Grom & 01 & $\begin{array}{l}\text { Descending } \\
\text { branch }\end{array}$ & $8 \times 8$ & $M C$ & $\begin{array}{l}\text { Primary } \\
\text { closure }\end{array}$ & Nal \\
\hline 9. & $24 \mathrm{M}$ & trauma & $\mathrm{NI}$ & $\begin{array}{l}\text { Left } \\
\text { ALT }\end{array}$ & $\mathrm{FC}$ & $\begin{array}{l}\text { Right grom, } \\
\text { scrotum \& } \\
\text { perineum \& left } \\
\text { Groin }\end{array}$ & 03 & $\begin{array}{l}\text { Descending } \\
\text { Branch }\end{array}$ & $\begin{array}{l}26 \mathrm{x} 13 \mathrm{c} \\
\mathrm{m}\end{array}$ & $\mathrm{MC}$ & SSG & Nil \\
\hline 10. & $48 \mathrm{M}$ & $\begin{array}{l}\text { CaPenis with } \\
\text { Post Ilioinguinal } \\
\text { block dissection } \\
\text { soft tissue defect } \\
\text { BL groin }\end{array}$ & Nel & $\begin{array}{l}\text { Right } \\
\text { and } \\
\text { Left } \\
\text { ALT }\end{array}$ & FC & B/L grom & 01 each side & $\begin{array}{l}\text { Descending } \\
\text { branch }\end{array}$ & $\begin{array}{l}8 \times 6 \\
10 \times 6\end{array}$ & $\mathrm{MC}$ & $\begin{array}{l}\text { Primary } \\
\text { both } \\
\text { side }\end{array}$ & Nil \\
\hline 11. & $32 \mathrm{M}$ & Trauma & NI & $\begin{array}{l}\text { Right } \\
\text { ped } \\
\text { Alt }\end{array}$ & $\mathrm{FC}$ & Inguinoscrotum & 01 & $\begin{array}{l}\text { Descending } \\
\text { branch }\end{array}$ & $7 \times 4$ & $\mathrm{MC}$ & $\begin{array}{l}\text { Primary } \\
\text { Closure }\end{array}$ & Nil \\
\hline 12. & $51 / \mathrm{M}$ & $\begin{array}{l}\text { Post illiomguinal } \\
\text { block dissection }\end{array}$ & Diabetic & $\begin{array}{l}\text { Left } \\
\text { ALT }\end{array}$ & FC & Inguinal region & 01 & $\begin{array}{l}\text { Descending } \\
\text { branch }\end{array}$ & $18 \times 10$ & $\mathrm{MC}$ & SSG & Nil \\
\hline 13. & $15 / \mathrm{M}$ & trauma & Nil & $\begin{array}{l}\text { Right } \\
\text { ALT }\end{array}$ & FC & Inguinoscrotum & 01 & $\begin{array}{l}\text { Descending } \\
\text { branch }\end{array}$ & $7 \times 5$ & $\mathrm{MC}$ & $\begin{array}{l}\text { Primary } \\
\text { Closure }\end{array}$ & Nil \\
\hline 14. & $34 M$ & $\begin{array}{l}\text { llioinguimal } \\
\text { wound dehiscnce }\end{array}$ & Diabetic & Left & $\mathrm{FC}$ & Ingumal region & 01 & $\begin{array}{l}\text { Descending } \\
\text { branch }\end{array}$ & $16 \times 9$ & SC & SSG & Nal \\
\hline 15. & $60 \mathrm{M}$ & $\begin{array}{l}\text { Foumier's } \\
\text { gangrene }\end{array}$ & Diabetic & $\begin{array}{l}\text { Left } \\
\text { ALT }\end{array}$ & $\mathrm{FC}$ & Serotum & 02 & $\begin{array}{l}\text { Transverse } \\
\text { Branch }\end{array}$ & $10 \times 5$ & $\mathrm{MC}$ & $\begin{array}{l}\text { Primary } \\
\text { Closure }\end{array}$ & $\mathrm{Nal}$ \\
\hline 16. & $21 / F$ & $\begin{array}{l}\text { Post traumatic } \\
\text { B.L. } \\
\text { inguinoscrotal } \\
\text { defect }\end{array}$ & $\mathrm{Na}$ & $\begin{array}{l}\text { Left } \\
\text { ALT }\end{array}$ & $\mathrm{FC}$ & Inguimoscrotum & 01 & $\begin{array}{l}\text { Descending } \\
\text { branch }\end{array}$ & $12 \times 9$ & $\mathrm{MC}$ & SSG & $\mathrm{Na}$ \\
\hline 17. & $34 \mathrm{M}$ & $\begin{array}{l}\text { Post Bums Rt. } \\
\text { sided } \\
\text { Inguinoscrotal } \\
\text { defect }\end{array}$ & $\mathrm{NEl}$ & $\begin{array}{l}\text { Right } \\
\text { ALT }\end{array}$ & FC & Inguinoscrotum & 02 & $\begin{array}{l}\text { Descending } \\
\text { branch }\end{array}$ & $7 \times 5$ & $\mathrm{MC}$ & $\begin{array}{l}\text { Primary } \\
\text { Closure }\end{array}$ & Nil \\
\hline 18. & $40 \mathrm{M}$ & $\begin{array}{l}\text { Post traumatic Lt. } \\
\text { inguinoscrotal } \\
\text { defect }\end{array}$ & Net & $\begin{array}{l}\text { Left } \\
\text { ALT }\end{array}$ & FC & Scrotum & 01 & $\begin{array}{l}\text { Descending } \\
\text { branch }\end{array}$ & $7 \times 5$ & $\mathrm{MC}$ & $\begin{array}{l}\text { Primary } \\
\text { Closure }\end{array}$ & Nal \\
\hline
\end{tabular}

MC: Musculocutaeous; SC: Septocutaneous; FC: Fasciocutaneous; SSG: Split Skin Graft

in addition.

\section{Surgical technique}

The ALT flap was designed following a well-described conventional pattern. The patient was first placed in a supine position. A line was drawn that joins the anterior superior iliac spine and the superolateral border of the patella (AP line), corresponding to the intermuscular septum between the rectus femoris and the vastus lateralis muscles [3]. The majority of perforators are located within a circle with a $3 \mathrm{~cm}$ radius bisecting the midpoint of the longitudinal axis and can be located using a $8 \mathrm{MHz}$ hand-held doppler probe [4].

Flap harvest was started with a medial incision which was 


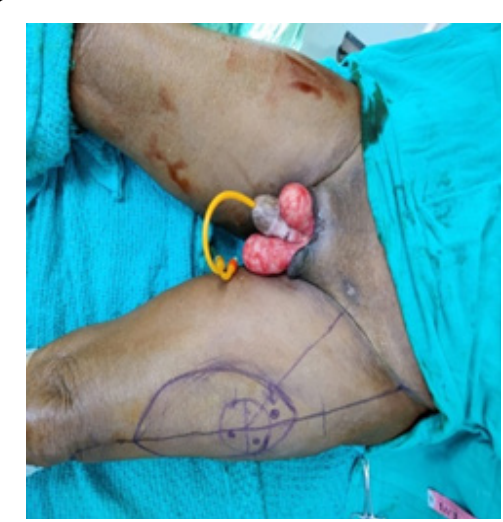

1A

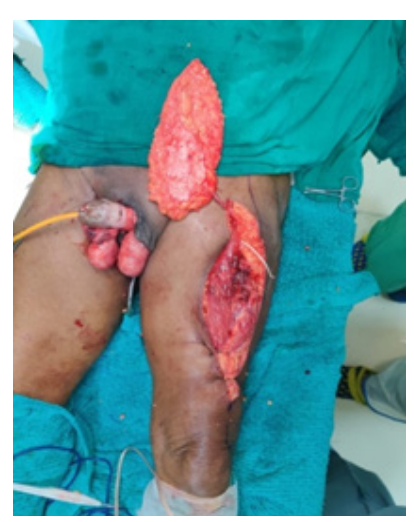

1B

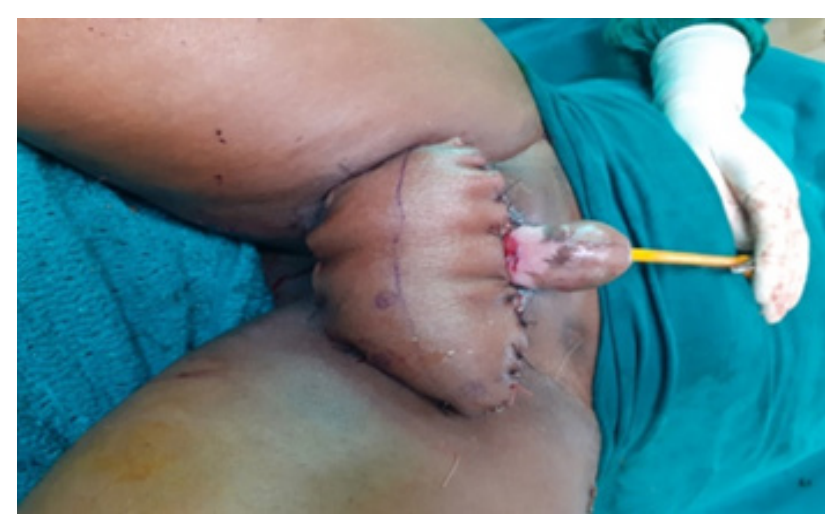

1C

Figure 1: 1(A, B and C): Left sided alt flap reconstruction of bilateral scrotal defect in a case of fournier's gangrene; 1A: Scrotal defect with flap markings; 1B: Flap raised; $1 \mathrm{C}$ : Insetting of flap

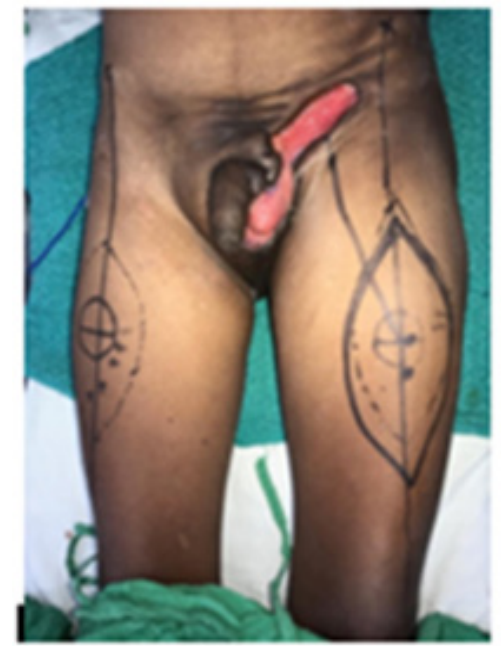

2A

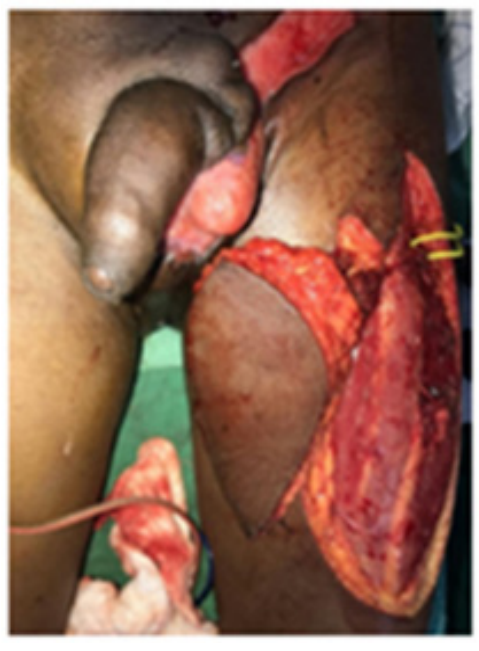

2B

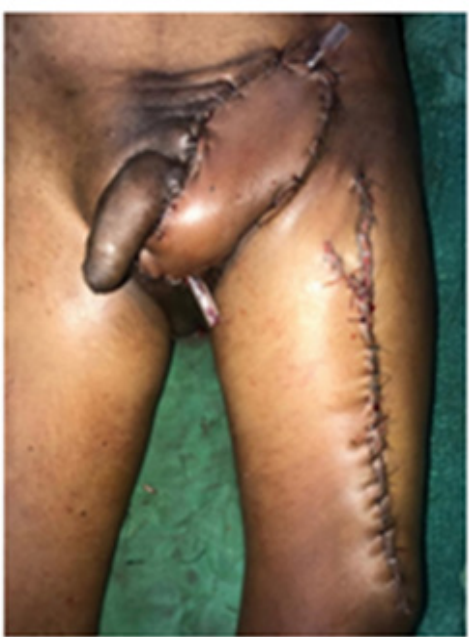

2C

Figure 2: 2(A, B and C): Left sided alt flap reconstruction of left sided post traumatic inguinoscrotal defect; 2A: Inguinoscrotal defect with flap markings; 2B: Flap raised; 2C: Insetting of flap with primary closed donor site.

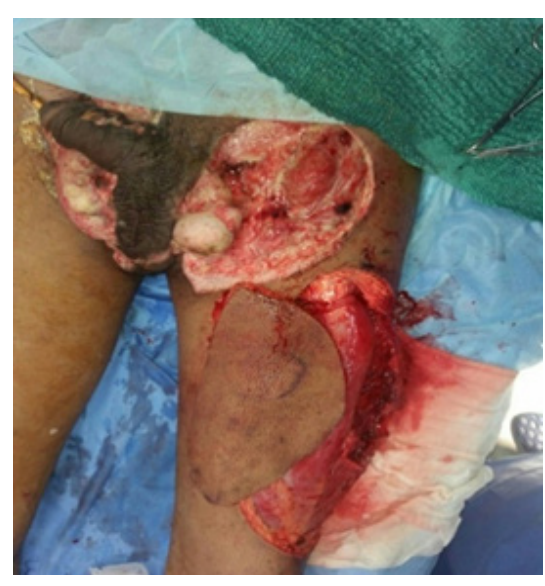

3A

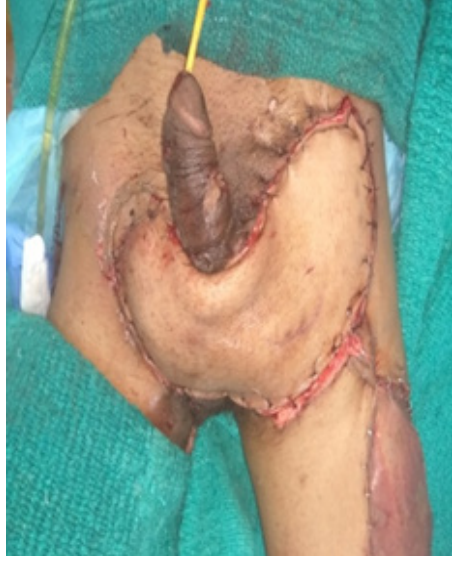

3B

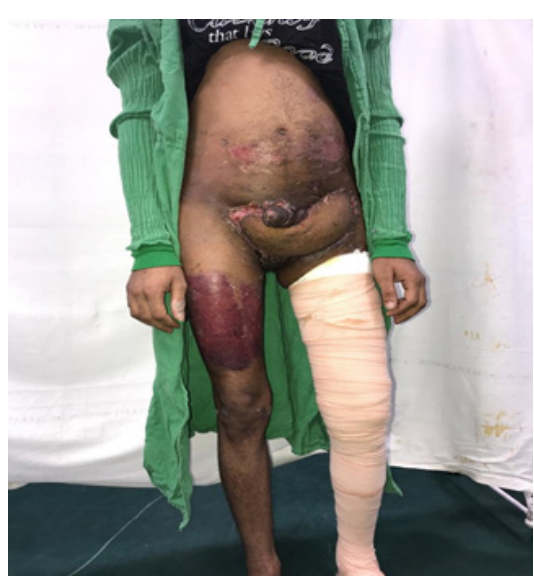

3C

Figure 3: 3(A, B and C): Left sided alt flap reconstruction of post traumatic bilateral inguinoscrotal defect; $3 \mathrm{~A}$ : $\mathrm{B} / \mathrm{L}$ inguinoscrotal defect and raising of flap; $3 \mathrm{~B}$ : Insetting of flap with ssg on donor site; 3C: Follow up after 6 weeks. 


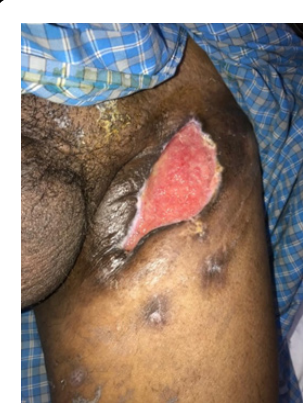

4A

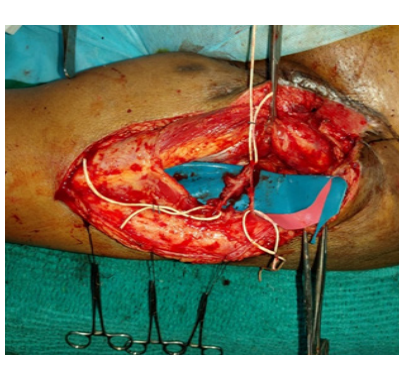

4B

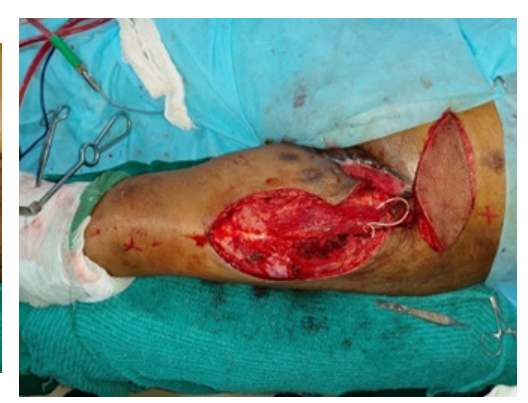

4C

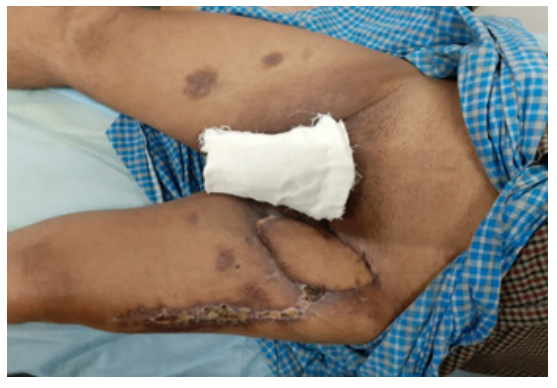

4D

Figure 4: 4(A, B, C and D): Left sided alt flap reconstruction of left sided post ilioinguinal dissection defect left groin; 4A: Left inguinal defect; 4B: Flap dissection with oblique and descending branches of LCFA; 4C: Raised flap; 4D: Follow up after 6 weeks.

made first and deepened upto the deep fascia above the rectus femoris muscle. Subfascial dissection was then continued until the intermuscular sptum was reached. Septum was opened from distal to proximal direction taking care not to injure the septocutaneous perforators. After the septum was opened, the descending branch of the Lateral circumflex femoral artery could be visualized.

The perforator to the skin paddle passes either through the intermuscular septum between the muscles or passes through the vastus lateralis. Once the perforator of sufficient caliber is identified, reorientation of the flap is done keeping two-thirds of the flap below the perforator. We prefer the distal perforator as the pedicle length is greater. Near the knee we do not include fascia in the flap to preserve the integrity of the quadriceps mechanism and to decrease the donor site morbidity. Posterior dissection of flap is completed and flap dissected towards the main descending branch of the lateral femoral circumflex artery. When pedicle dissection had been completed, and we were sure of position of perforator, pivot point and length of the pedicle, the flap was harvested with or without underlying fascia lata, or with only a part of it, according to the defect; in case of pelvic exenteration dead space, we used to harvest vastus lateralis muscle with the flap. To reach the defect, it was always necessary to create a tunnel under rectus femoris muscle and inguinal skin taking care to preserve the saphenous vein, when not ligated during groin dissection. For more medial defects such as exclusive perineal defects, a tunnel under Sartorius muscle was even necessary. The donor site was closed primarily in layers or by using a split-thickness skin graft, depending on the width of the flap harvested and patient characteristics. Primary closure of the fascia is needed if suprafascial flap harvesting is done. After surgery, all the patients were placed on bed rest, with urinary catheter, liquid diet, for 1 week. They were then allowed to stand and gradually walk. The sutures were removed 14 days postoperatively.

\section{Results}

19 pedicled ALT flaps were used for the coverage in 18 patients and all flaps were survived well except 1 flap develop venous congestion in immediate post operative period due to tension over vascular pedicel which was managed by increasing pedicle length.

The main perforator supplying the flap was originated from the descending branch in 17 flap patients and transverse branch in

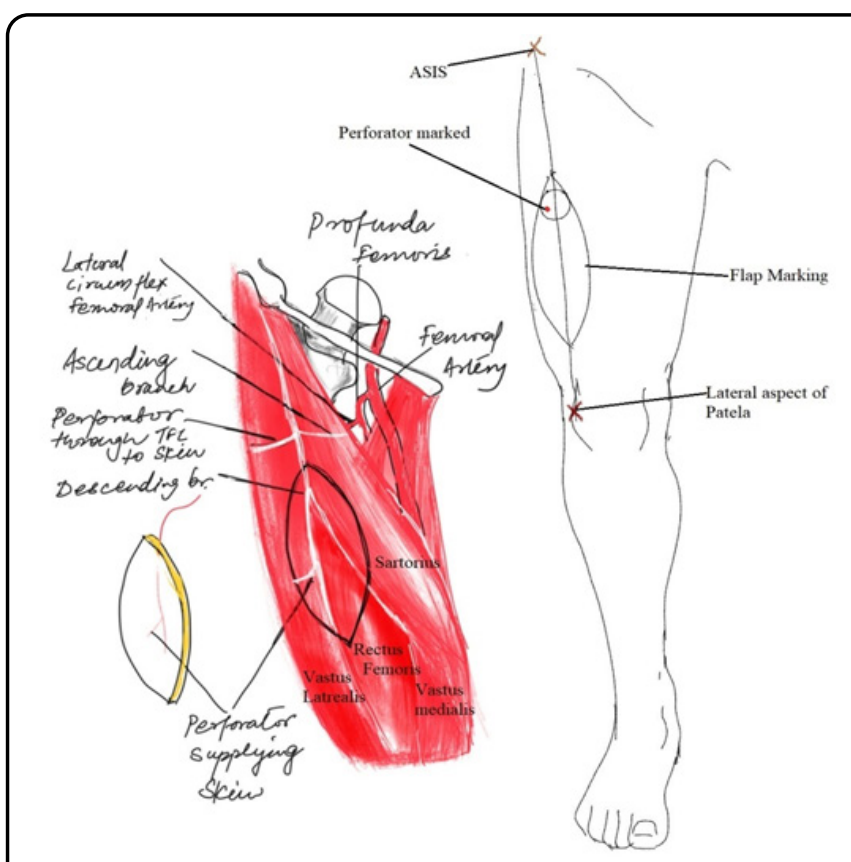

DLAGRAM : RIGHT SIDED ALT FLAP MARKINGS AND RELATED VASCULAR ANATOMY

Figure 5: Diagramatic representation of flap markings and vascular anatomy.

2 flaps. The perforators on which the flaps were based included 17 musculocutaneous perforators and two septocutaneous perforators. In one flap 3 perforators were included, while in 3 of the total flaps, 2 perforators were included and the remaining 15 flaps were based on single perforator. The flap containing 3 perforators was additionally happened to be the largest flap elevated. The average flap size was $11.8 \mathrm{~cm}$ long $\times 7.2 \mathrm{~cm}$ wide (range $7 \times 4 \mathrm{~cm}$ to $26 \times 13 \mathrm{~cm}$ ), while the mean pedicel length was $10 \mathrm{~cm}$ (range, 7-13 cm). Out of 18 patients, 17 were males and 1 female. The average age of the patients was 44 years. All the patients were followed up for an average period of 6 months, ranging from 1 to 12 months. Donor site morbidity was minimal. 2 patients had developed partial loss of the skin graft at the donor site which got healed secondarily in due course. No freshly developed functional deficit of the lower limb was noted in any patient. 18 flaps were done for groin and Inguinoscrotal defects the length of the pedicle ranged from 7 to $13 \mathrm{~cm}$ (Mean-10 cm). In 19 flaps donor sites 13 were closed primarily and 06 were split skin grafted. In one flap the transverse branch was additionally ligated and 
additional proximal dissection up to its origin from Profunda femoris gave an additional $3 \mathrm{cms}$ to the pedicel length. 2 flaps were tunneled under rectus femoris one was used to cover scrotum and another was used to cover opposite Inguinoscrotal region. The flap was tunneled under the rectus femoris which provided unfolding of the $6 \mathrm{~cm}$ and $12 \mathrm{cms}$ long pedicel in respective flaps for easier swing to the opposite groin.

\section{Discussion}

Different strategies of inguinoscrotal reconstruction are delineated that depends upon the quantity of tissue loss, amount of infection, restoration of function and cosmesis of exposed testicles and finally the cause.

Reconstructive choices for inguinoscrotal groin comes from the ipsilateral thigh as muscle (rectus femoris, sartorius and tensor fascia lata) or myocutaneous extensions or skin flaps like ALT flap (septocutaneous or myocutaneous) or local and random flaps. The local random skin flap transposition isn't enough to cover the large composite defect because the latter needed both good filler and a cover.

Placement of testicles inside upper thigh subcutaneous pocket has been used extensively, however it's the drawbacks of lack of temperature regulation, pain and atrophy of testicles. These factors alongwith adverse psychological effects typically supports the relocation of testes at anatomical position. Despite of the limited evidence concerning testicular histology and spermatogenesis and subsequent ability to father, scrotal reconstruction is recommended worthwhile $[5,6]$. A split skin graft has additionally been used to resurface the testicles however it leads to contraction compromising the gametogenesis and hormonal production. Further more skin graft in perineal area are usually unsatisfactory secondary to maceration and breakdown.

For larger inguinoscrotal defects use of local fasciocutaneous or musculocutaneous flaps are advocated. Medial thigh fasciocutaneous and superomedial thigh fasciocutaneous flaps have additionally been used which can lead to compromised cosmesis. Hsu et al., [7] used a modified gracilis myofasciocutaneous advancement flap with good results for perineoscrotal defect but mobile scrotum is difficult to create with this technique. Murakami et al., [8] used large partially thinned abdominal flap based on both inferior epigastric arteries to cover the extensive scrotal defect. Abdominal wall herniation is the drawback of this procedure.

Since the first description of ALT flap by Song et al., [1] as a free flap, it's been deliniated for ipsilateral groin, trochanteric, ischial and genital defects as a proximally based flap and for knee defects as distally. Yu et al., [6] used the ALT thigh flap for perineoscrotal reconstruction in 7 patients. Similarly Luo et al., [9] reported a case of perineal reconstruction using ALT thigh flap with good results. Wang et al., [10] used the same flap for perineum reconstruction in 18 patients with good results. $\mathrm{Ng}$ et al., [11] reconstructed neighbouring defects of groin and penile region using pedicled ALT flap.

The most employed traditional abdominis distant flaps include VRAM flap and gracilis flap. VRAM flap has robust vascularisation however needs the sacrifice of rectus muscle, with risk of hernia, and isn't safe in the presence of abdominal weakness, or if it's necessary to comprehend each colostomy and urostomy [12]. TFL flap has unreliable vascularity in its distal portion and creates unacceptable dog ear deformity. While rectus femoris muscle flap might cause weakness of knee extension based flap clinical scenarios. Lannol et al., [13] delineated the largest series of the proximally pedicled ALT for abdominal and pelvic re-construction. They described the farthest reach of the ALT flap i.e., lower costal margin, PSIS, anterior margin of anus, and contralateral iliac fossa. Tunnelling the flap beneath rectus and sartorius might increase the reach of flap by reducing the tension on the pedicel.

The advantages of ALT flap includes minimal donor site morbidity as majority of wounds can be closed primarily, long vascular pedicel with wide arc of rotation, ability to resist the infection, the possibility of combining the flap with other tissues, proximity of the flap to the defect and finally chance to convert it into a sensate flap, makes it as one of the ideal flap option for inguinoscrotal wound defects. Inspite of all advantages of a pedicled ALT flap there are some disadvantages of using such flap such as variation in the vascular supply, intramuscular dissection for musculocutaneous type perforators and colour mismatch which are to be taken into consideration.

Our study was conducted to evaluate the use of pedicled anterolateral thigh flap for reconstruction of defects around inguinoscrotal regions in 18 patients. We had found that the musculocutaneous perforator to be commonest perforator type observed in about $89 \%$ of total cases and most commonly arising from the descending branch of LCFA. Authors have also advised the division of transverse branch of LCFA to gain the extra pedicle length and tunneling of flap under rectus femoris muscle if opposite groin or scrotum is to be covered. We do not find any dependence of flap viability on number of perforators to be included. We also advise inclusion of distal thigh skin for better reach of flap in distant areas. No such study has been reported in any of the recognized journal in India involving such a large number of patients series in the past. All flaps were survived well except 1 flap develop venous congestion in immediate post operative period due to tension over vascular pedicle which was managed by increasing pedicle length. 2 patients developed partial loss of the skin graft at the donor site which got healed secondarily in due course. Donor site morbidity was minimal.

\section{Conclusion}

Pedicled ALT flap is a versatile, reliable flap, with wide arc of rotation which makes it as an ideal flap for the coverage of defects around Inguinoscrotal region.

\section{Decalaration:}

The study is in accordance with the ethical standards of the responsible committee on human experimentation (Institutional or Regional) and with the Helsinki Declaration of 1975, as revised in 2000.

\section{Ethics approval and consent to participate:}

Duly informed consent was obtained in all the cases. The study was approved by the Institutional Ethic Committee.

\section{Conflict or interest:}

The authors declare that they have no competing interests. 


\section{Consent for publication:}

Consent to publish has been obtained.

\section{Availability of data and material:}

Please contact author for data requests.

\section{Funding:}

None.

\section{Acknowledgment: \\ Not applicable.}

\section{References}

1. Song YG, Chen GZ, Song YL (1984) The free thigh flap: A new free flap concept based on the septocu- taneous artery. $\mathrm{Br} J$ Plast Surg 37: p. 149.

2. Gudaviciene D, Milonas D (2008) Scrotal reconstruction using thigh pedicle flaps after scrotal skin avulsion. Urol Int 81: pp. 122-124.

3. Liu Y, Zang M, Zhu S, et al. (2018) Distally based anterolateral thigh flap pedicled on the oblique branch of lateral circumflexfemoral artery. J Xiangya Med 3: p. 17.

4. Kawai K, Imanishi N, Nakajima H, et al. (2004) Vascular anatomy of the anterolateral thigh flap. Plast Reconstr Surg 114(5): pp. 1108-1117.

5. Spyriounis PK (2009) Scrotum reconstruction with the anterolateral (ALT) thigh flap. Eur J Plast Surg 32: pp. 123-126.

6. Yu P, Sanger J, Matloub HM, et al. (2002) Anterolateral thigh fasciocutaneous island flaps in perineoscrotal reconstruction. Plast Reconstr Surg 109: p. 610.

7. Hsu H, Li CM, Sun TB, et al. (2007) Unilateral gracilis myofasciocutaneous advancement flap for single stage reconstruction of scrotal and perineal defects.J Plast Reconstr Aesthet Surg 60(9): p. 1055.

8. Murakami M, Hyakusoko H, Matsuzawa I, et al. (2001) Scrotal reconstruction with a thinned flap based on both inferior epigastric arteries. Scand J Plast Reconstr Hand Surg 35: p. 99.

9. Luo S, Rafful W, Piaget F, et al. (2000) Anterolateral thigh fasciocutaneous flap in the difficult perineogenital reconstruction. Plast Reconstr Surg 105: p. 171.

10. Wang X, Qiao Q, Burd A, et al. (2006) Perineum reconstruction with pedicled anterolateral thigh flap. Ann Plast Surg 56: p. 151.

11. Ng RWM, Chan JYW, Mok V, et al. (2008) Clinical use of a pedicled anterolateral thigh flap. J Plast Reconstr Aesthet Surg 61: p. 158.

12. Villa M, Saint-Cyr M, Wong C, et al. (2011) Extended vertical rectus abdominis myocutaneous flap for pelvic reconstruction: Three-dimensional and four-dimensional computed tomography angiographic perfusion study and clinical outcome analysis. Plast Reconstr Surg 127(1): pp. 200-209.

13. Lannon DA, Ross GL, Addison PD, et al. (2011) Versatility of the proximally pedicled anterolateral thigh flap and its use in complex abdominal and pelvic reconstruction. Plast Reconstr Surg 127(2): pp. 677-688. 